\title{
Aspects of Fossil Botany.
}

\author{
By Dr. D. H. SсоTT, F.R.S.
}

\section{Early Floras.}

$D^{\mathrm{R}}$ . CHURCH has reminded us that "the Beginnings of Botany are in the Sea." This is undoubtedly true, whether we accept his hypothesis of a universal ocean, or hold that the surface of the cooling earth was so corrugated that seas and continents co-existed from the first. The Plankton stage, of microscopic, free-swimming organisms, postulated by Dr. Church, has left no trace in the rocks. We have, however, abundant evidence of the early presence of marine plants. Apart from some disputable Cambrian records, we have numerous well-preserved seaweeds from the Ordovician onwards. It is, of course, mainly calcareous Algæ which have lent themselves to fossilisation. The verticillate Siphoneæ, above all, form a fine evolutionary series, admirably investigated by Dr. Julius Pia, of Vienna. Their interest has perhaps scarcely been sufficiently recognised by botanists, though among geologists Prof. Garwood has emphasised the importance of calcareous Algæ as rock-builders. The Siphoneæ, however, form a line of their own, without any relation to the land-flora with which we are now concerned.

At some unknown period the transmigration to dry land took place. If we accept the theory of continents and oceans as equally ancient, it is quite probable that there may have been successive transmigrations. As we shall see, highly organised land-plants occur about contemporaneously with apparently primitive types. Dr. Bidder, in his address to Section D (Zoology) of the British Association in 1927, pointed out the probability of the early appearance of land-organisms. He regarded the occurrence of extensive beds of graphite in pre-Cambrian rocks as evidence of an abundant vegetation in land-locked waters, with every opportunity of migration on to the neighbouring shores. Thus a land-vegetation may have made an early start, and some of the descendants may have persisted among later floras. It is suggested that Hugh Miller's ' cone-bearing tree" of the Middle Devonian may have been such a survival. To quote Dr. Bidder's words: "There may be a class or classes of terrestrial animals or plants which have breathed air two or three times as long as those which left the sea in the Devonian."

We have, however, as yet no perfectly trustworthy record of land-plants earlier than the Lower Devonian. First of all there is the classical, but once disputed, Psilophyton of Dawson, with its rhizome, forked aerial stems, bearing thorns but no leaves, and large terminal sporangia. There seems to be little doubt that Dawson's description was essentially correct. The contemporary Arthrostigma was like a larger Psilophyton.

The oldest known land-plant with well-preserved structure is Gosslingia breconensis, recently discovered by Dr. Heard in the Lower Devonian of South Wales. In habit this was something like Psilophyton; the branches, as in that genus, had circinate tips. It is a curious fact that circinate venation, often found in these early plants, is older than the frond itself, for it occurs on thalloid branches not yet differentiated as leaves. Gosslingia had a well-developed vascular cylinder, considerably larger than in the somewhat later Rhyniaceæ. The wood was evidently developed centripetally, contrary, as it appears, to the direction in the family just mentioned. Stomata were detected, as in the contemporary Psilophyton, in which Mr. W. N. Edwards demonstrated them very clearly. The great antiquity of the typical stoma is interesting, but not surprising, for we know that this organ is common to Bryophytes and vascular plants. Gosslingia also possessed terminal bodies which are interpreted as sporangia.

It is unnecessary to recapitulate the characters of the Middle Old Red Sandstone Rhyniacex, now familiar to botanists. A word may be said as to their relation to the Bryophytes, as indicated chiefly in the somewhat Sphagnum-like sporogonium of Hornea and Halle's Sporogonites. Dr. Church has gone so far as to say that "Rhynia and Hornea between them present all the characters deduced as significant for early Bryophyta"; and Prof. Bower, with more caution, maintains that "the new facts are thus seen to link the Bryophytes and the Pteridophytes more closely together than ever before." We may accept this latter statement, and then the question arises whether these supposed Devonian intermediates were on the up-grade or the down-grade. Were they on the way to become full-blown Pteridophytes, or in course of reduction to a moss-like level ? Here we will only recall Haberlandt's opinion that the mosses were reduced forms. At that time one asked: But reduced from what? Possibly the Rhyniaceæ may suggest an answer.

The late Dr. Arber, at a time when only Rhynia was known, took a different view, for he thought that this genus represented "a now obsolete race of Thallophyta." He was so far justified that the Rhyniaceæ in their external morphology are no more complex than some purely thalloid seaweeds, such as Polyides or Pycnophycus. It is an interest-. ing question whether any of the other early fossils suggest an algal connexion. Hicklingia of Middle, and Zosterophyllum of Lower Old Red Sandstone age, both have a somewhat alga-like habit, and yet were probably (certainly in the latter case) vascular plants. Pseudosporochnus (Middle Devonian), the largest of all these plants, probably $10 \mathrm{ft}$. high, with a bulbous base, thick stem and numerous fine branches, has all the appearance of a big seaweed, but this too was a vascular plant. Forstia furcata, an Upper Devonian fossil, though fragmentary, combines algal structure with the spores and cuticle of a land-plant. As Kidston and Lang say, it " almost serves to break down any sharp distinction between Algæ and the

No. 3097, Vol. 123] 
simplest Pteridophyta." Milleria (formerly Ptilophyton), on the other hand, "appears to approach, without reaching, the more definitely fern-like forms that come into evidence in the Upper Devonian "(Lang).

We may now leave these simpler types and pass on to definitely leafy plants, such as the genus Asteroxylon. The Rhynie species, A. Mackiei, is now well known. It will be remembered that the connexion of the associated sporangia and sporangiophores with the plant has never been proved. The German species, A. elberfeldense, of perhaps somewhat later age, serves to remove any doubt, for the plant bore, towards the summit, naked branches, resembling the Rhynie sporangiophores, and in two cases sporangia were found upon them. Kräusel and Weyland's species combined the external features of the form-genera Thursophyton, Psilophyton, and Hostimella. It differs in definite respects from $A$. Mackiei, notably in the apparent presence of a pith in the stele of the main axis. Thus Asteroxylon appears really to present the extraordinary combination of characters attributed to it by Kidston and Lang - the anatomy and vegetative habit of a Lycopod, with a reproductive apparatus suggesting that of some of the Carboniferous ferns. Another early plant, looking like a Lycopod, is Protolepidodendron, only known by its external features.

Among Kräusel and Weyland's discoveries at Elberfeld, in the Upper Middle Devonian, are the two oldest known Articulatæ, Hyenia and Calamophyton. The most interesting point is the fructification, which in each case consists of a lax cone, bearing no bracts, but only sporangiophores, which are forked and support pendulous sporangia. The absence of bracts in these 'Protoarticulatæ' supports the view of Lady Isabel Browne that these sterile organs were a later intercalation in the Calamarian cone.

The variety of Early Devonian plants was naturally far greater than the few better-known types here mentioned would indicate. For example, Prof. Lang, in his assiduous investigation of the Old Red Sandstone flora of Scotland, found eight different kinds of spore in the fish-beds of Cromarty. They run up to $400 \mu$ in diameter, and some may thus have been megaspores. One type has been identified by Kräusel and Weyland with the spores of the Elberfeld tree-fern Aneurophyton germanicum.

Aneurophyton was a tree-fern in habit, but its afflnities are quite uncertain. All parts of the plant are known: stem, root, fronds, and, to a certain extent, the fructification. There was much secondary wood, resembling that of Palceopitys Milleri. Quite recently the primary wood has been discovered. It was solid and three-lobed in transverse section, recalling that of the Lower Carboniferous genus Stenomyelon. It is a remarkable fact that all parts of the frond show stemstructure. Only the ultimate leaflets are regarded as truly foliar; they have no vascular strand at all-hence the generic name. The sporangia are borne in clusters on special leaflets. The plant bears a general resemblance to Eospermatopteris, but there is no evidence of seeds. Palceopitys Milleri (Middle Old Red of Cromarty), as just mentioned, has somewhat similar wood-structure to that of Aneurophyton, but nothing is known of its habit. The structure, while not that of a typical Gymnosperm, is more like a Gymnosperm than anything else, and to that extent may justify the discoverer's bold description of it (in 1847) as a "cone-bearing tree." At any rate it is a highly organised plant to find at so low a horizon.

Returning to the Elberfeld records, we must note the remarkable discovery of a Middle Devonian Cladoxylon (C. scoparium), the oldest species known, and the only one in which the external habit and something of the fructification are shown. The complex anatomy is exactly that of the wellknown species first described by Unger in 1856. The leaves are numerous, small, forked appendages, very different from the large fronds which, on anatomical evidence, appear to have characterised the Thuringian Cladoxylons. It has been suggested by Dr. Hirmer that the genus (following the analogy of Asteroxylon) possessed leaves of two categories, the small appendages of the Elberfeld species representing Lygnier's 'phylloids,' while the massive fronds of the later forms were true leaves derived from modified branch-systems. The sporangia of $C$. scoparium were borne on the margins of lobed outgrowths, differing in shape from the vegetative foliage. Nothing was found to support the hypothesis that Cladoxylon belonged to the Pteridosperms.

We have, in fact, apart from Eospermatopteris, no direct evidence for the occurrence of seed-plants in Devonian times. The leaves of the genus Psygmophyllum, which goes back at least to the Middle Devonian, are somewhat like those of the Maidenhair tree, and appear to have belonged to woody plants. One may imagine that we have in them an early race of Gymnosperms, but habit is notoriously deceptive. A fossil found in the Middle Old Red Sandstone of both Orkney and Caithness, named Hostimella racemosa by Lang, bears lateral bodies which may be either sporangia or seeds ; no spores could be obtained from them, but neither is there any evidence of seed nature.

We now come to Eospermatopteris, the tree of the fossil forest of Gilboa in the State of New York. A great flood on the Schoharie Creek exposed five stumps in 1869. They were referred to Sir William Dawson, who named them as two species, Psaronius erianus and $P$. textilis. It turned out to be true that the plants were really tree-ferns in habit. In recent years further exposures have revealed hundreds of stumps scattered over a district $1 \frac{2}{3}$ miles in length, and occurring at three different levels. The stumps attain a diameter of 3 feet or more. Portions of the stem and large compound fronds of the plants are associated with the rooted stumps. Seeds were first detected by Dr. Ruedemann in 1920. There are numerous specimens associated with fragments of the fronds. They were investigated by Miss Goldring, who has published full and excellent descriptions; to her the name Eospermatopteris is due. The seeds are

No. 3097, VoL. 123] 
borne, often in pairs, on stalks; they are about $5.6 \mathrm{~mm}$. long by $3 \mathrm{~mm}$. broad, and are described as cupulate. They appear to be perfectly clear seeds, so far as impressions can show. Male organs, rather large terminal discs, with apparent impressions of sporangia on the lower surface, have also been observed. This, then, is the oldest seedplant known, for the age is undoubtedly no later than Upper Devonian.

We may now briefly review the results of our rapid survey. Recent research has revealed, in the Early Devonian, vascular plants far simpler in structure than any known before. We can no longer regard these simpler types as reduced, for there are too many of them. With these primitive forms, however, much more advanced types are associated, possibly, as Dr. Bidder suggests, the survivors of an earlier land-flora.

Lignier's theory of the double origin of the leaf, from emergences forming 'phylloids,' on one hand, and from thallus branches forming true leaves, on the other, seems to find strong confirmation from the early flora, as, for example, in Asteroxylon. In many cases the circinate tips of thalloid branches clearly indicate incipient fronds.

On the whole, the data now available favour the rise of the land-flora from a well-developed thalloid stock of marine origin, which branched out into the two main Archegoniate lines, the mosses and the ferns.

\section{The Progress of Marine Propulsion.}

\section{By Engineer Captain Edgar C. Sмiтh, O.B.E., R.N.}

$\mathrm{N}^{\mathrm{k}}$

EVER since Fulton launched the Clermont or Bell built the Comet has there at any time been a fixed or standard type of machinery for all ships. Inventions, improvements, innovations have followed in rapid succession, and the history of marine engineering presents an endless and bewildering variety of engines and boilers which have been adopted one day, only to be superseded by better ones the next. With all this change and development, however, designers have never before been faced with the problem of choosing between so many rival methods of driving ships as they have to-day, each method of propulsion making by its performance or promise some claim to consideration. Modern marine engineering embraces inits scope not only steam boilers and steam engines, but also steam turbines, oil engines of various types, and also the use of electricity on an extensive scale.

One of the most notable steps in the progress of the marine engine was the adoption of compound working associated with the name of John Elder; another the introduction of the triple expansion engine by Alexander Kirk ; another stage in marine propulsion was marked by the application of the Parsons steam turbine; while to-day there is an everincreasing fleet of ships driven by Diesel oil engines. The advance made during the last sixty years will be realised by comparing the Cunard ships of 1869 with modern liners. Then, no Cunard ship used more than $30 \mathrm{lb}$. pressure in her boilers; the greatest horse-power in any ship was 4200, found in the Scotia; while the coal consumption was $3-3 \frac{1}{2} \mathrm{lb}$. per h.p. per hour. To-day, ships are running with $350-400 \mathrm{lb}$. pressure; the total horse-power of a big Atlantic liner is 70,000-80,000; while in the most modern steam machinery less than $\frac{3}{4} \mathrm{lb}$. of oil per h.p. per hour is used. At one time, Great Britain built 80 per cent of the steamships of the world. Owing to various causes, one of which is the rise of great shipbuilding yards abroad, this proportion has fallen considerably; yet the volume of construction and marine engineering remains very large, and there is no slackening of the effort to maintain our position. For a long period marine engineering was largely a matter of experienee and rule-of-thumb, but to-day it is not only influenced at every stage by scientific research, but sometimes very costly large-scale experiments are made and the industry is ready to try out any new system which offers reasonable expectation of success. Very great popular interest was taken formerly in the records of the ships of the 'Atlantic ferry,' the blue riband of which has now been held for twentytwo years by the famous Mauretania. During the coming summer, the new German turbinedriven liners Europa and Bremen are due for completion, and it may be that for a time the Atlantic record will pass to Germany as it did some thirty years ago.

Apart from the new machinery for very large and fast ships, however, there are many developments taking place, and a few particulars of recent marine practice may be of value to those who, though not directly associated with marine engineering, may nevertheless be engaged in the study of some of the numerous problems which are connected with it. Marine engineering to-day owes very much to the mathematician, the chemist, the physicist, and the metallurgist.

Confining this article to recent steam practice, it is proposed to give a few notes on up-to-date boiler work and then refer to some recent improvements in reciprocating engines, steam turbines, and electric transmission gear. At first simply great square or oblong boxes with internal flues, or with banks of tubes in place of flues, sixty years ago the box boilers gave way to the eylindrical or Scotch boilers, and these have been used until recently almost without exception in merchant ships. Such boilers are suitable for steam pressures up to $200 \mathrm{lb}$. or even $250 \mathrm{lb}$. pressure, but with still higher pressures, marine engineers have had to follow naval engineering practice and use one or other of the many types of water-tube boilers, of which the Babcock and Wilcox and the Yarrow are favourite examples.

In the successful working of water-tube boilers, a supply of pure water free from grease or scaleforming substances is an absolute necessity. In high pressure steam vessels the condenser is

No. 3097, Vol. 123] 